\title{
Investigation and Classification of the outsourcing barriers to implementation of Green Supply Chain Management in the Iranian oil refining industry using DEMATEL- ANP (The Case Study: Isfahan Oil Refining Industry)
}

\author{
Faraz Etezazian
}

Department of Management, Najafabad Branch, Islamic Azad University, Najafabad, Iran

\author{
Maryam Akhavan Kharazi \\ Department of Business adminastration, Shahid Beheshti University, Tehran, Iran
}

\author{
Masoud Barati \\ Department of Management, Najafabad Branch, Islamic Azad University, Najafabad, Iran
}

DOI: 10.6007/IJARBSS/v5-i10/1855 URL: http://dx.doi.org/10.6007/IJARBSS/v5-i10/1855

\begin{abstract}
Today the manufacturing industries have started to use "green concept" in their supply chain management, which focused on environmental issues. These industries are still trying to identify barriers to the implementation of green supply chain management (GSCM). The main goal of this study is to rank obstacles to the implementation of GSCM in the oil refining industry (Case Study: Isfahan Oil Refinery).

Due to the highly specialized aspect of this research, the sampled individuals in this study consisted of experts (middle and top managers) with adequate knowledge and at least five years of work experience in Isfahan Oil Refinery. The index levels of this survey have been achieved through questionnaires taken by these experts. Hence, this study will offer new and innovative approaches to identify obstacles to the implementation of GSCM in Iran's oil refining industry.A targeted non-probabilistic sample of 35 experts was identified. The indexing, ranking and rating of the analytic network process (ANP) has been determined once the distributed questionnaires were completed by the selected individuals.

Key Words: supply chain management, Green supply chain management, Environmental management, supplier and green buy.

Introduction

Today international organizations are finding themselves in a very competitive situation. Environmental performance improvement can be a strong differentiation versus their competitors. Improving environmental performance has become essential for organizations
\end{abstract}


because of increasing pressure from governmental and non-governmental organizations and customer awareness on environmental compliance issues.

The manufacturing or services organizations who implemented a strategy to improve the environmental performance of the supply chain obtained a lot of advantages and benefits such as energy savings, emissions reducing, waste reduction or elimination, and finally productivity improvements. In recent years, some issues such as improving the environmental performance have led to the new concept of GSCM. It covers all the stages of a product life, from design to recycling.

Industries and various organizations have implemented several activities to reach the GSCM. Up to now, only a few of the research studies have analysed barriers to implement the GSCM. In addition, the researchers did not analyse the various industrial factors and most studies focused on a limited number of obstacles. It is clear that there aren't many programs to identify the major obstacles for implementation of GSCM. This research is to address this gap. The aim of this study is to evaluate and classify the barriers to implementation of Green Supply Chain Management in the Iranian oil refining industry in Isfahan based on one of the newest models on the "barriers to implementation of green supply chain". This model has been presented by Govindan et al. (2014).

\section{Literature Review}

- Govindan et al (2014), entitled "Analysis of barriers to run green supply chain management in India's industries using Analytical Hierarchy Process", which examines the barriers in supply chain management (SCM), and in which 47 factors are investigated in detail.

- Su Qin et al., 2011, entitled "Ensuring supply chain quality performance through applying the Supply Chain Operation Reference (SCOR) model", which focuses on the importance of quality and quality requirements throughout the supply chain, the need to have a structure and information architecture to be able to monitor, track quality requirements and create records and quality control measures at the level of the supply chain.

- Lee et al (2011), entitled "Information Architecture for Supply Chain Quality Management", which examines the relationship between programs and practices "to ensure quality supply chain" and "supply chain performance" within the SCOR Model. In this study the statistical population was 232 Chinese companies which had ISO 9000 certification. They showed every key processes of SCOR model (planning, survey, construction, delivery and return) collate effectively with quality management system of ISO 9000. The supply chain quality management greatly increased in 3 Key performance indicators associated with customers (reliability, responsiveness with flexibility and cost). Also from internal research carried out in this field can be referred to the following:

- Zanjirchi et al (1392), entitled "A framework based on environmental performance assessment of green manufacturing and phased approach" having as an objective to present a framework in order to evaluate the level of implementation of GSCM in manufacturing industries and propose an approach to increase its implementation. This is done using fuzzy multi-criteria decision-making approach, focusing on 5 criteria: green supply and buy, green design, green 
production, green transportation and green categories. The result of this study showed tiles, textile and steel industries ranked respectively 1 to 3 in terms of being green.

- Nilipour et al (1391), entitled "Optimizing the use of information technology in the supply chain management and marketing the air products by AHP". In this study, the author identify the main objectives of supply chain and apply information technology to identify and optimize supply chain management processes. The results suggested that trained resources in the IT field would be able to support senior management with existing soft and hardware sub-structures, e-commerce and electronic transmission of data with business partners.

-Olfat et al (1390), entitled "Fulfil the requirements of the automotive industry's green supply chain management," investigated requirements to achieve the GSCM in the Iranian automotive industry. The study showed 3 key priorities: the environment, waste management and environmental cooperation with stakeholders. Survey shows similar findings with studies conducted in China among automotive and power generation industries.

\section{Research methodology}

The study used Govindan et al (2014) one of the newest model of implementing barriers of GSCM. This model consists of five primary barriers.

The conceptual model is shown as follows.

1- Upstream Supply Chain (SC): the first obstacle of the study is complexity of evaluating and monitoring of suppliers and lack of adequate legal leverages to implement environmental laws.

2- Knowledge: one of the barriers is lack of knowledge and training about important environmental issues. Lack of awareness about environment issues can also be mentioned as another barrier.

3- Technology: one of the important barrier is lack of appropriate infrastructure for information and communication technology and relationship sub-structures in order to facilitate the implementation of GSCM.

4- Participating and supporting: lack of top and middle managers support and lack of active and voluntary approach of organizations and suppliers about maintenance environmental standards and social responsibility in organizations. This leads to difficulty to obtain the GSCM.

5- Financial: another barrier is high cost of implementation like high investment, low capital return, financial constraints, etc. (Govindan et al, 2014). 
Elimination of implementation barriers of green supply chain management

\begin{tabular}{l|l|l|l|l|}
\hline financial & supporting & technology & knowledge & Upstream SC \\
\hline-
\end{tabular}

The study first mentioned a comprehensive literature review and secondly investigated the existing barriers of implementing the GSCM in the Iran oil refining industry (Case study: Isfahan oil refining industry).

The study then identifies barriers from upstream supply chain to GCSM implementation in the Iranian oil refining industry, by surveying (questionnaires) a population of experts (managers) of the Isfahan oil refining industry. Results were finally prioritized using ANP methodology.

\section{Hypothesis}

1- To what extent external factors such as government, competitors, traditional mentality of suppliers and ... prevent the green supply chain management?

2- To what extent traditional mentality (conflict in benefits versus protection of environment) prevented to obtain green supply chain management?

3- To what extent the complexity of monitoring on suppliers environmental approaches prevented to obtain green supply chain management?

4- To what extent incorporation of suppliers in environment protection prevented to obtain green supply chain management?

5- To what extent potential conflict of production with environmental laws prevented to obtain green supply chain management?

6- To what extent lack of strength in the governmental regulations to acceptance of policies of friendly environment prevented to obtain green supply chain management?

7- To what extent inappropriate reward system for suppliers in order to acceptance of policies of friendly environment prevented to obtain green supply chain management?

\section{Research Methodology \\ Type of study}

This study is a descriptive survey and forms an objective point to applied research. The study objective is to investigate and prioritize existing barriers from the experts (managers) perspective of industry in the implementing of green supply chain management in the Iran oil refining industry.

Statistical population, sampling method and sample size according to the research is specialized, statistic population are experts (middle and top managers) who have great experience in the supply chain management and chose in the different sectors of environment 
management as experts of this study. The number of Isfahan oil refining industry is 132 . The number of statistic samples the study is 35 experts that chose by non-probability sampling.

\section{Data collection method}

The data in this survey and prestigious library that go to libraries, networking and technical documents related to banking centres to collect data and information will be discussed.

\section{Data analysis methods}

Partnership and supporting criteria relationship table

\begin{tabular}{|c|c|c|c|c|c|}
\hline $\begin{array}{c}\text { Participation and } \\
\text { supporting }\end{array}$ & financial & knowledge & technology & outsourcing & Cumulative \\
\hline 2.2 & 1.8 & 1.6 & 1 & 0 & Outsourcing \\
\hline 1.6 & 1.6 & 1.6 & 0 & 2 & Technology \\
\hline 2.4 & 1.6 & 0 & 2.8 & 2.6 & Knowledge \\
\hline 1.8 & 0 & 2.6 & 2.6 & 2.2 & Financial \\
\hline 0 & 2 & 1.8 & 1.8 & 1.8 & $\begin{array}{c}\text { Participation } \\
\text { and } \\
\text { supporting }\end{array}$ \\
\hline
\end{tabular}

Whole relationship between criteria calculated by DEMATEL way.

\begin{tabular}{|c|c|c|c|c|c|}
\hline $\begin{array}{c}\text { Participation and } \\
\text { supporting }\end{array}$ & financial & knowledge & technology & outsourcing & Cumulative \\
\hline 0.955599 & 0.845803 & 0.872462 & 0.869066 & 0.807168 & Outsourcing \\
\hline 0.919125 & 0.837322 & 0.878683 & 0.77494 & 0.992658 & Technology \\
\hline 1.205132 & 1.042076 & 0.94625 & 1.234443 & 1.275632 & Knowledge \\
\hline 1.163017 & 0.894919 & 0.94625 & 1.22803 & 1.250752 & Financial \\
\hline 0.83721 & 0.925021 & 0.956682 & 1.003965 & 1.046524 & $\begin{array}{c}\text { Participation } \\
\text { and } \\
\text { supporting }\end{array}$ \\
\hline
\end{tabular}

Determining the criteria importance

Compare paired did by 5 teams which as follows:

Paired comparison table

\begin{tabular}{|c|c|c|c|c|c|}
\hline $\begin{array}{c}\text { Participation } \\
\text { and } \\
\text { supporting }\end{array}$ & financial & knowledge & technology & outsourcing & \\
\hline 2.70192 & 2.091279 & 2.825235 & 1.430969 & 1 & outsourcing \\
\hline 1.888175 & 1.084472 & 2.352158 & 1 & 0.698827 & technology \\
\hline 0.922108 & 0.435275 & 1 & 0.425141 & 0.353953 & knowledge \\
\hline 2.047673 & 1 & 2.297397 & 1 & 0.478176 & financial \\
\hline 1 & 0.488359 & 1.084472 & 0.529612 & 0.401371 & $\begin{array}{c}\text { Participation } \\
\text { and } \\
\text { supporting }\end{array}$ \\
\hline
\end{tabular}


The solve result of 5 teams with consistent rate of matrixes and cumulative matrix consistent rate as follows:

Inconsistent rate table

\begin{tabular}{|c|c|c|c|c|c|c|}
\hline E-T & $E 5$ & $E 4$ & $E 3$ & $E 2$ & $E 1$ & \\
\hline 0.337722 & 0.360423 & 0.326184 & 0.229281 & 0.304872 & 0.413275 & outsourcing \\
\hline 0.229129 & 0.200413 & 0.258259 & 0.386144 & 0.147436 & 0.159165 & Technology \\
\hline 0.103068 & 0.106457 & 0.137809 & 0.144837 & 0.078718 & 0.058471 & Knowledge \\
\hline 0.213347 & 0.236777 & 0.177046 & 0.109542 & 0.321538 & 0.259376 & Financial \\
\hline 0.116735 & 0.09593 & 0.100702 & 0.130196 & 0.147436 & 0.109713 & $\begin{array}{c}\text { Participation } \\
\text { and } \\
\text { supporting }\end{array}$ \\
\hline 0.013848 & 0.019867 & 0.098511 & 0.038059 & 0.046287 & 0.028793 & CR \\
\hline
\end{tabular}

Step 3: determine sub- criteria weight Comparisons between sub- criteria cumulative matrix such as outsourcing and technology as follows:

sub- criteria table

\begin{tabular}{|c|c|c|c|c|c|c|}
\hline $\mathrm{C} 16$ & $\mathrm{C} 15$ & $\mathrm{C} 14$ & $\mathrm{C} 13$ & $\mathrm{C} 12$ & $\mathrm{C} 11$ & \\
\hline 1.084472 & 0.870551 & 1.643752 & 0.740214 & 2.70192 & 1 & $\mathrm{C} 11$ \\
\hline 0.608364 & 0.467044 & 0.922108 & 0.349414 & 1 & 0.370107 & $\mathrm{C} 12$ \\
\hline 1.605483 & 1.148698 & 2.825235 & 1 & 2.861938 & 1.35096 & $\mathrm{C} 13$ \\
\hline 0.698827 & 0.740215 & 1 & 0.353953 & 1.084472 & 0.608364 & $\mathrm{C} 14$ \\
\hline 1.245731 & 1 & 1.35096 & 0.870551 & 2.141127 & 1.148698 & $\mathrm{C} 15$ \\
\hline 1 & 0.802742 & 1.430969 & 0.622865 & 1.643752 & 0.802742 & $\mathrm{C} 16$ \\
\hline
\end{tabular}

Weight table of outsourced sub- criteria

\begin{tabular}{|c|c|c|c|c|c|c|}
\hline E-T & $E 5$ & $E 4$ & $E 3$ & $E 2$ & $E 1$ & \\
\hline 0.189951 & 0.121945 & 0.357052 & 0.21382 & 0.164727 & 0.096774 & C11 \\
\hline 0.089523 & 0.069801 & 0.13312 & 0.084278 & 0.06929 & 0.065781 & C12 \\
\hline 0.258951 & 0.347435 & 0.199071 & 0.132022 & 0.26001 & 0.250552 & C13 \\
\hline 0.111349 & 0.244984 & 0.149766 & 0.07856 & 0.079009 & 0.043659 & C14 \\
\hline 0.195262 & 0.143731 & 0.072324 & 0.144368 & 0.281286 & 0.38194 & C15 \\
\hline 0.154964 & 0.072104 & 0.088666 & 0.346951 & 0.145679 & 0.161295 & C16 \\
\hline 0.002494 & 0.069934 & 0.043348 & 0.036318 & 0.024827 & 0.009036 & CR \\
\hline
\end{tabular}

As you can see in the table 7, C13 criteria or nonparticipation of suppliers in protection of environment allocated the most weight among outsourcing factors and showed suppliers participation is the most important factor in outsourced criteria. 
Super matrix ANP table

\begin{tabular}{|c|c|c|c|}
\hline E2 & C1 & G & \\
\hline- & 0 & 0 & G \\
\hline- & 0.12666 & 0.337722 & C1 \\
\hline- & 0.029807 & 0 & C11 \\
\hline- & 0.014048 & 0 & C12 \\
\hline- & 0.040634 & 0 & C13 \\
\hline- & 0.017473 & 0 & C14 \\
\hline- & 0.03064 & 0 & C15 \\
\hline- & 0.024317 & 0 & C16 \\
\hline
\end{tabular}

with square of above matrix criteria weight and sub- criteria by ANP as follows: Normalized sub- criteria, then ranked. The results by AHP as follows:

\begin{tabular}{|c|c|c|}
\hline waits & outsourcing & Variable \\
\hline 0.071 & $\begin{array}{c}\text { C1 } \\
\text { suppliers }\end{array}$ & C11 \\
\hline 00.0429 & Problem in maintaining the environmental \\
\hline 0.0202 & Complexities in measuring/ monitoring & C12 \\
\hline 0.0585 & Environmental partnership with suppliers & C13 \\
\hline 0.0251 & Products potentially conflicting laws & C14 \\
\hline 0.0441 & Lack of government support to adopt & C15 \\
\hline 0.035 & $\begin{array}{c}\text { No proper training and reward system for } \\
\text { suppliers }\end{array}$ & C16 \\
\hline
\end{tabular}

\section{Result of the ranking ANP table}

\begin{tabular}{|c|c|c|c|c|}
\hline \multicolumn{2}{|c|}{ AHP } & \multicolumn{2}{c|}{ ANP } \\
\cline { 1 - 3 } Rank & Gred & rank & grad & \\
\hline 3 & 0.010066 & 3 & 0.071871 & C11 \\
\hline 14 & 0.004744 & 6 & 0.033842 & C12 \\
\hline 1 & 0.013723 & 1 & 0.098006 & C13 \\
\hline 7 & 0.005901 & 5 & 0.042051 & C14 \\
\hline 2 & 0.010348 & 2 & 0.073882 & C15 \\
\hline 4 & 0.008212 & 4 & 0.058636 & C16 \\
\hline
\end{tabular}

The questions number 1 to 6 is related to outsource criteria as follows:

1- Lack of suppliers' participation in environment protection.

2- Not being strength of governmental regulations to acceptance of environment friendly policies.

3- Suppliers' traditional mentality (conflict in benefits with protection of environment). 
4- Inappropriate reward system for suppliers in order to accept of environment friendly policies.

5- The most important sub- criteria are respectively (according to 10 table):

6- As mentioned the most important barrier to implementation of green supply chain management in the Iran oil refining industry is outsourcing.

7- Therefor it's necessary the industry is overall managers more concentrate and consider

it. For this purpose it's necessary create an expert team for evaluate performance of suppliers and evaluate participate and nonparticipant of suppliers in protection of environment and eliminate or punish or encourage it according to policy. In addition the organization can conduct related awareness and training programs in order to familiar suppliers with environmental issues and governmental regulations and promote their field to correct implement of green supply chain.

\section{References}

\section{English}

1- Ahi, P. (2015). An analysis of metrics used to measure performance in green and sustainable supply chains, www.elsevier.com , Vol. 86 No. 14, pp. 360-377.

2- Beatriz, a. (2015). Understanding the genesis of green supply chain management: lessons from leading Brazilian companies, Journal of Cleaner Production, Vol. 87 No17, pp. 385-390.

3- Cheng, T., Hong, X., Ming, L. (2014). Research on pricing and coordination strategy of green supply chain under hybrid production mode, Journal of Computers \& Industrial Engineering, Vol. 72 No. 10, pp. 120-132.

4-Calleja, I., Delgado, L., Eder, P., Kroll, A., Lindblom, J., Wunnik, C., Wolf, O., Gouarderes, F., Langendorff, J. (2004). Promoting environmental technologies: sectoral analyses barriers and measures. IPTS Report EUR 21002EN . Institute for Prospective Technological Studies, Seville, Vol. 50 No. 14, pp. 381-395.

5-Darrin, S. (2005). Herbs \& botanicals update: opportunely is still knocking in the herbs and botanicals segment, Amazon journal, Vol. 78 No. 13, pp. 238-243.

6-Govindan a,n, Mathiyazhagan Kaliyan a,c, Devika Kannan b, A.N. Haq. (2014). Barriers analysis for green supply chain management implementation in Indian industries using analytic hierarchy process, International Journal of Production Economics, Vol. 35 No. 14, pp. 555-568.

7-Hillary, R. (2004). Environmental management systems and the smaller enterprise, Journal of Cleaner Production, Vol. 12 No. 6, pp. 561-569.

8- Lin, R., (2015), Using fuzzy DEMATEL to evaluate the green supply chain management practices, Journal of Cleaner Production, Vol. 40 No. 14, pp.32-39.

9 -Li Ling, S., Chen Xu. (2011). Ensuring supply chain quality performance though applying the SCOR model, International Journal of production Research, Vol. 12 No. 1, pp. $33-57$. 
10-Ming, L., Lin, Y., Tan, K., Chen, R., Chen, Y. (2014). Using TODIM to evaluate green supply chain practices under uncertainty, Applied Mathematical Modelling, Vol. 38 No. 10, pp. 2983-2995.

11- Rostamzadeh, R., Govindan, K., Esmaeili, A., Sabaghi, M. (2015). Application of fuzzy VIKOR for evaluation of green supply chain management practices49, Journal of Ecological Indicators, Vol. 49 No.12, pp. 188-203.

\section{Persian}

12-Nili poor, S., tabatabaie, M., Khayamian, A., Karbasian, M., Shariaty, M. (1391), optimaization using information technology in green chain management and flight products marketing with AHP approach, new marketing reacerchs, Vol. 2 No. 2, pp. 4752.

13-Olfat, L., khatamy, A., khodaverdy, R. (1390). Eligible of green chain management accomplish in the Iran automobile industry, management Sciences, Vol. 6 No. 21, pp. 1-140.

14-Zanjirchi, M., Esmailian, F., Azizi, F., Moravej, S. (1392). frame presentation evaluating green production industry based on environmental performance, Enviromentlogy, Vol. 2 No. 1, pp. 39-52. 